Al-Ta'a: Softened Truss Model Theory for the Analysis of Fibre Reinforced Concrete Deep

\title{
Softened Truss Model Theory for the Analysis of Fibre Reinforced Concrete Deep Beams and Corbels
}

\author{
S. A. Al-Ta'an, Professor \\ Department of Civil Engineering, \\ Mosul University, IRAQ \\ N. S. H. Al-Husaini, Assistant lecturer \\ Dept. of Building and Construction, \\ Technical Engineering College, Mosul \\ Corresponding author, S. A. Al-Ta'an, Email: saad.altaan@yahoo.com
}

Reinforced concrete members may be subjected to axial load, bending moment, shear and torsion. However the behaviour of these members under shear or combined shear and torsion is a complex phenomenon.

In this study the softened truss model theory is applied for the analysis of fibre reinforced concrete deep beams and corbels. The theory is more promising than the strut and tie model which satisfies the equilibrium conditions and to some extent materials constitutive relationships. While this theory, considers the equilibrium, compatibility, materials constitutive relationships and the degrading effect of the diagonal tension cracks on the compressive strength of cracked reinforced concrete element when subjected to biaxial compression-tension stresses. The previously developed algorithms for the analysis were modified by incorporating the effect of short discrete steel fibres on the behaviour and strength of concrete subjected to shear.

Fibre reinforced concrete deep beams and corbels were analyzed using the adopted algorithm and materials constitutive relationships. The predicted effects of the shear span / depth ratio, volume fraction of steel fibres and the longitudinal steel ratio on the shear strength of fibre reinforced concrete deep beams and corbels showed good agreement with published experimental results.

Keywords: corbel, deep beam, reinforced concrete, shear, softened truss, steel fibres.

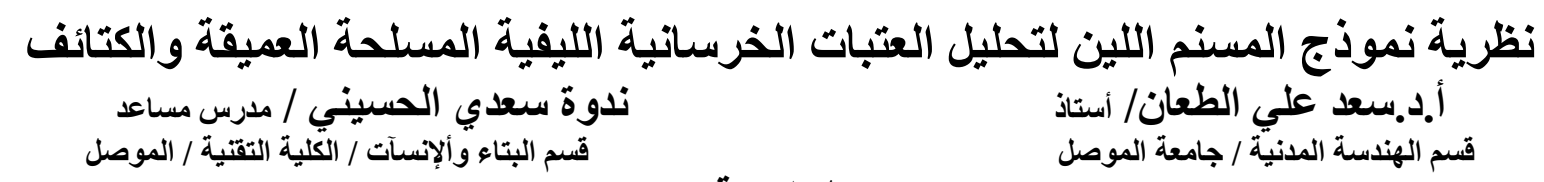

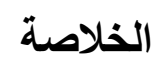

قسم الهندسة المدنية / جامعة الموصل الطعل

الأعضاء الخرسانية المسلحة قـ تتعرض إلى أحمال محورية، عزوم انثناء، قوى قص وعزئة وعزوم لي. سلوك هذه الأعضاء تحت

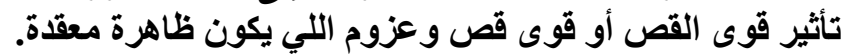

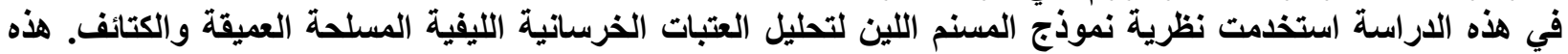

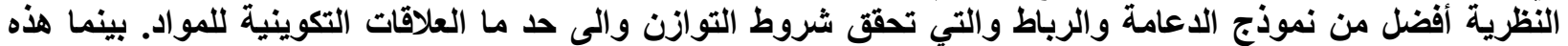

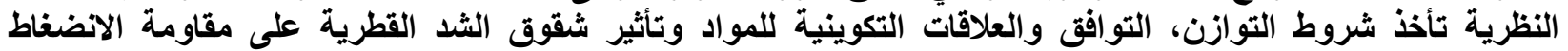

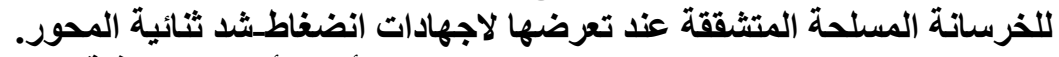

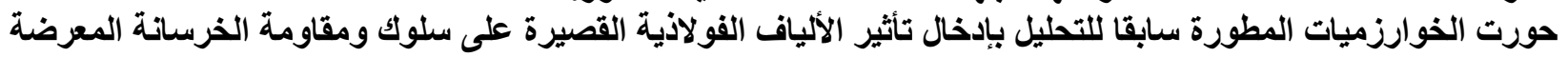
إلى قوى قصن.

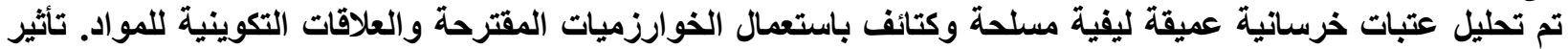
فضاء القص/ العمق، حجم الألياف الفولاذية ونسبة التسليح الطولي على مقاومة القص لفئلة للعثبات العميقة والكتائف أظهرت توافقا جيدا مع النتائج العملية المنشورة

Received: 28 - 6 - 2013

Accepted: 7 - 10 - 2013 


\section{Introduction}

Beams with small span to depth ratio are called deep beams and short cantilever beams with a shear span less than or equal to their effective depth are called corbels or brackets. Their behaviour and strength have been the subject of numerous experimental studies [1-3].

Several possible modes of failure have been identified from the published test results, but the predominant one is that of shear failure. The shear action in the beam web leads to compression in a diagonal direction and tension in the perpendicular direction. The observation of web crack before failure leads to a theoretical model that assumes the dependency of shear strength on concrete splitting strength. On the other hand, a simple model that recognizes the arch action in deep beam has been proposed to predict web compression failure.

Combining the equilibrium, compatibility and softened stress-strain relationships, a theory was developed which can predict with good accuracy the test results of various types of reinforced concrete structures subjected to shear or torsion [4-6]. The theory can predict not only the shear and torsion strengths, but also the deformations of a structure throughout its post-cracking loading history. This theory is called the softened truss model theory to emphasis the importance of the concrete softening phenomenon. It has been successfully used to predict the shear strength of low-rise shear walls, shear strength of framed wall panels, shear transfer strength across an initially uncracked shear plane, torsion strength of beams, and membrane strength of shell elements [7-9].

A reliable prediction for the shear strength of shear critical members using the softened truss model theory requires the existence of both longitudinal and transverse reinforcement. Niranjan and Patil [10] introduced an effective transverse compression in the beam web to predict accurately the shear strength of deep beams with vertical web reinforcement.

Steel fibres improve the compressive, tensile, shear and impact strength of plain concrete, increase the strain capacity and thus impart ductility to plain concrete [11]. Since shear failure is initiated by diagonal tensile stresses, the presence of steel fibres will retard shear cracks initiation and increase the shear strength in reinforced concrete shear critical members like deep beams, corbels and flat slabs where shear is dominant [1-3].

In this study the softened truss model theory was applied to predict the shear strength of fibre reinforced concrete deep beams and corbels. The influence of the shear span/depth ratio, the longitudinal, transverse and steel fibre reinforcement were taken into account in predicting the shear strength.

\section{Materials Constitutive Relationships Fibrous concrete in compression}

The stress-strain curve proposed for fibre concrete by Hsu et al.[12] is used in this study:

$$
\frac{f_{c}}{f_{c f}}=\frac{\beta\left(\varepsilon / \varepsilon_{f o}\right)}{\beta-1+\left(\varepsilon / \varepsilon_{f o}\right)^{\beta}}
$$




\section{Al-Ta'a: Softened Truss Model Theory for the Analysis of Fibre Reinforced Concrete Deep}

where $f_{c}$ is the stress at strain $\varepsilon, f_{c f}$ is the compressive strength of fibrous concrete, $\varepsilon_{f_{o}}$ is the strain at peak stress and taken as proposed by Soroushian and Lee [13]:

$\varepsilon_{f o}=0.0021+0.0007 V_{f} l_{f} / d_{f}$

$V_{\mathrm{f}}, \mathrm{l}_{\mathrm{f}}$ and $\mathrm{d}_{\mathrm{f}}$ are the volume fraction, length and diameter of the fibres respectively, and $\beta$ is a variable that depends on the fibres parameters:

$\beta=1.093+0.7132 R^{-0.926} \quad$ for hooked fibres

$\beta=1.093+7.4848 R I^{-1.387} \quad$ for smooth fibres

where RI is a fibres reinforcing index equals to $R I=w_{f} l_{f} / d_{f}$, where $w_{f}$ is the fibres weight fraction. The strain capacity in compression increases also with the fibres and the Equation proposed by Abdul-Razzaque [14] is used in this investigation:

$\varepsilon_{\text {cuf }}=\left(3011+2295 V_{f}\right) 10^{-6}$

When concrete is subjected to biaxial tension - compression, softening will occur, i.e.; the compression strength will be reduced due to the presence of tensile stresses in the orthogonal direction. The following softening coefficient proposed by Belarbi and Hsu [15] is used in this investigation:

$\delta=0.9 / \sqrt{1+400 \varepsilon_{r}}$

$\varepsilon_{\mathrm{r}}=$ principal tensile strain, this softening coefficient is used for the stress and strain in Eq. (1).

\section{Fibrous concrete in tension}

The ascending part of the curve (OA) is similar to that of plain concrete up to first cracking, Fig.(1):

$f_{t}=E_{c} \cdot \varepsilon_{t} \leq f_{t}^{\prime}$

$E_{c}=$ initial modulus of plain concrete, $\epsilon_{t}=$ tensile strain and $f_{t}^{\prime}=$ tensile strength of plain concrete and in this investigation assumed equal to $0.5 \sqrt{f_{c}^{\prime}}$. A nonlinear region usually follows $(\mathrm{AB})$ due to the increase in microcracks width and propagation up to the peak or the tensile strength of the composite $\left(f_{t f}\right)$, which is assumed equal to that proposed by Soroushian and Lee [13]:

$f_{t f}=f^{\prime}\left(1+0.016 N_{f}^{1 / 3}+0.05 \pi d_{f} l_{f} N_{f}\right)$

$\varepsilon_{t f}$ is the corresponding strain. $N_{f}=$ number of fibres per unit area $=4 \eta_{o} v_{f} /\left(\pi d_{f}^{2}\right)$ and $\eta_{o}=$ orientation factor $=0.41$.

In the absence of test data $\varepsilon_{t f}$ can be taken as proposed by Soroushian and Lee [13]: 


$$
\varepsilon_{t f}=\varepsilon_{t}^{\prime}\left(1+0.35 N_{f} d_{f} l_{f}\right)
$$

After the composite reaches its tensile strength $f_{t f}$, a sudden drop occurs in the tensile stress strain diagram (BC) due to the formation of a continuous crack and the stress transfer from the matrix to the fibres. The stress at this stage is equal to the post cracking tensile strength and equals to:

$f_{u}=N_{f} \cdot \tau_{u} \cdot \pi \cdot d_{f} \cdot l_{f} / 4$

$\tau_{u}=$ bond strength of the steel fibres and in this investigation taken as proposed in Ref. [13]:

$$
\tau_{u}=\left(2.62-0.0036 N_{f}\right) K_{f}
$$

$K_{f}=$ surface shape factor for the steel fibres $=1.0$ for smooth fibres, 1.25 for hooked fibres and 1.5 for crimped fibres [16].

The descending part of the curve (CD) in Fig. (1) is controlled by the following Eq.:

$$
\sigma=f_{u}\left[\left(\varepsilon_{i}-\varepsilon_{m}\right) /\left(\varepsilon_{t f}-\varepsilon_{m}\right)\right]^{2}
$$

The limiting tensile strain $\left(\epsilon_{m}\right)$ at which complete separation of the two crack faces occur is taken equal to 0.1 as proposed by Sakai and Nakamura [17].

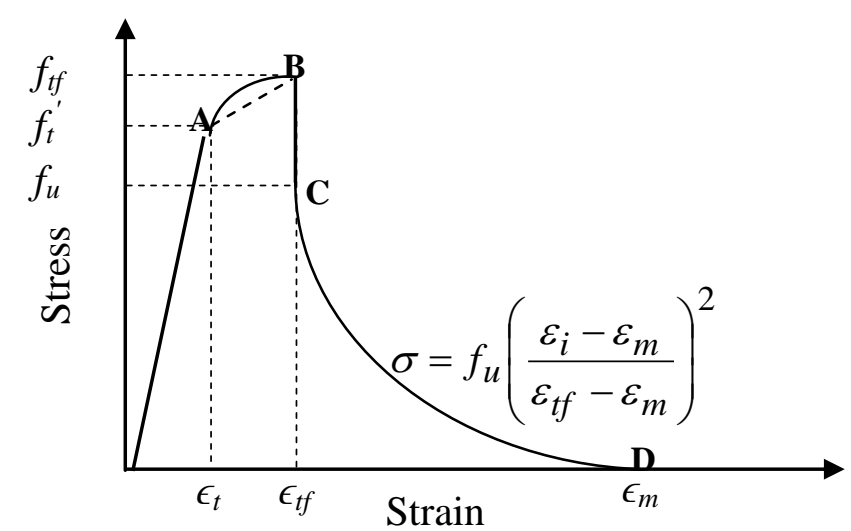

Figure (1) Stress-strain relationship for fibrous concrete in tension

The stress - strain relationship shown in Fig.(1) is modified to a continuous function as proposed in Ref. [18] as follows

$$
f_{t}=a^{\prime} \cdot \varepsilon_{t} /\left(\varepsilon_{t}^{3}+b^{\prime} \cdot \varepsilon_{t}^{2}+c^{\prime} \cdot \varepsilon_{t}+d^{\prime}\right)
$$

The constants $a, b, c$ and $d$ can be found from the points $\mathrm{A}, \mathrm{B}$ and any other point on the descending part $\mathrm{CD}$. The fourth equation is found from the property that the slope of the curve at the peak point equal to zero. 


\section{Modulus of Elasticity of Fibrous Concrete}

For fibre reinforced concrete, the equation proposed by Hsu et al. [12] is used in this investigation:

$$
E_{c f}=E_{c}+0.941 \times 10^{6}(R I)
$$

The Equation proposed by Carraquillo et al. [19] for the modulus of elasticity of plain concrete in the above equation is used in this investigation:

$$
E_{c}=3320 \sqrt{f_{c}^{\prime}}+6895
$$

\section{Stress - Strain Relationship of Steel}

The reinforcing bars are assumed to have the same properties in tension and compression and follow an elastic (up to the yield point) perfectly plastic behavior.

\section{Solution of Equations of Softened Truss Model Theory}

When a reinforced concrete element is subjected to shear stresses and compressive and tensile stresses in two perpendicular directions, cracks will develop at an angle $(\alpha)$ with longitudinal steel direction (l), Fig.(2). The truss action will be composed by the concrete between the cracks, which resist the compressive stresses, and the reinforcement which resist the tensile stresses. From Fig.(2), three equilibrium equations can be written:

$$
\begin{gathered}
\sigma_{l}=\sigma_{d} \cos ^{2} \alpha+\sigma_{r} \sin ^{2} \alpha+\rho_{l} \cdot f_{l} \\
\sigma_{t}=\sigma_{d} \sin ^{2} \alpha+\sigma_{r} \cos ^{2} \alpha+\rho_{t} \cdot f_{t} \\
\tau_{l t}=\left(\sigma_{d}-\sigma_{r}\right) \sin \alpha \cos \alpha
\end{gathered}
$$

Other three compatibility equations can be written for the concrete strains which satisfy Mohr's strain circle:

$$
\begin{aligned}
& \varepsilon_{l}=\varepsilon_{d} \cos ^{2} \alpha+\varepsilon_{r} \sin ^{2} \alpha \\
& \varepsilon_{t}=\varepsilon_{d} \sin ^{2} \alpha+\varepsilon_{r} \cos ^{2} \alpha \\
& \gamma_{l t}=2\left(\varepsilon_{d}-\varepsilon_{r}\right) \sin \alpha \cos \alpha
\end{aligned}
$$

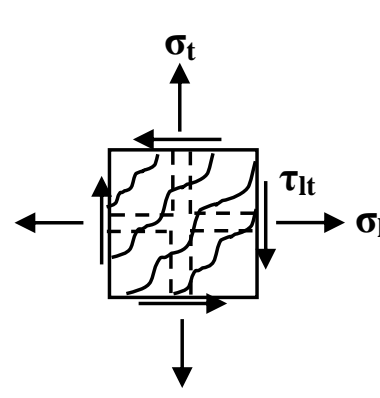

(a)

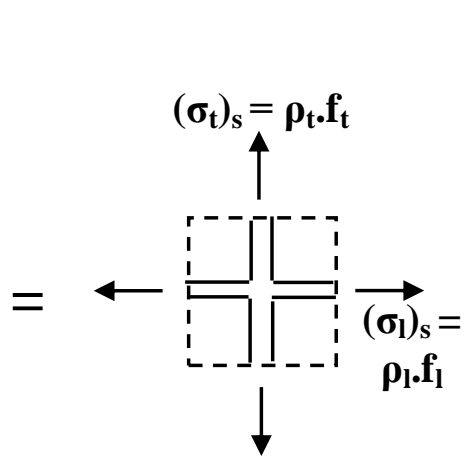

(b)

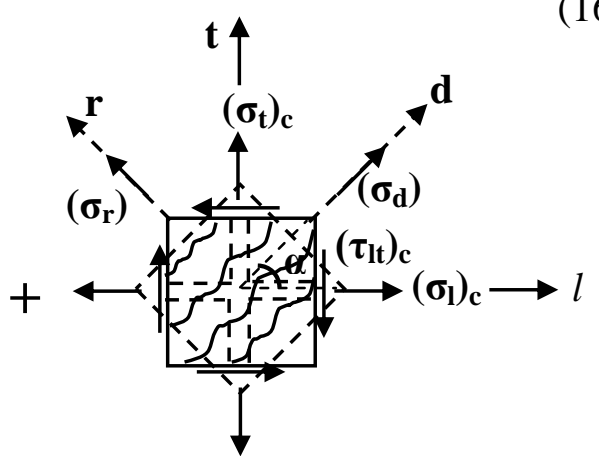

(c)

Figure (2) Truss model for reinforced concrete element, (a) stresses on cracked elements, (b) stresses on steel, (c) stresses on concrete $[4]$ 


\section{Analysis of Deep Beams}

A deep reinforced concrete beam that is loaded with two symmetrical shear forces is shown in Fig. (3), the shear span should not exceed (2h). The bending moment is resisted by the top and bottom steel while the shear force is resisted by the truss action in the web shown by the dashed rectangle whose depth $=d_{v}=d_{e}-d$. The truss action requires that there are horizontal and vertical reinforcement. When there is no top steel, $d$ ' may be taken as half the depth of the compression stress block (a/2). The small element inside the dashed zone shown in Fig. (3) is subjected to shear and vertical stresseVequal to:
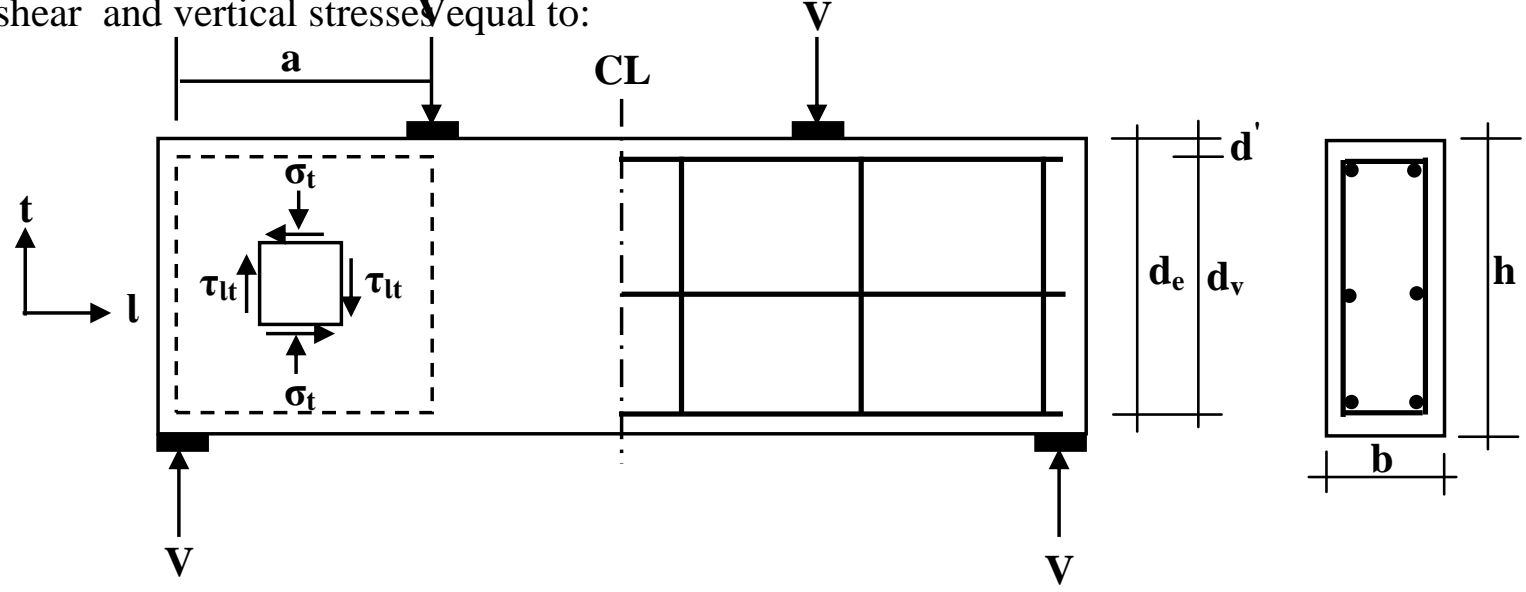

Figure (3) Stresses state in a Reinforced Concrete Deep Beam [5]

$$
\begin{array}{ll}
\tau_{l t}=V /\left(b . d_{v}\right) & \\
\sigma_{t}=V /(b . a)=2 . V /(b . h) & \text { for } \mathrm{a} / \mathrm{h} \leq 0.5 \\
\sigma_{t}=V /(b . a)[4 / 3-(2 / 3)(a / h)] & \text { for } 0.5<\mathrm{a} / \mathrm{h} \leq 2.0
\end{array}
$$

Since both the shear and vertical stresses are proportional to the shear force V, they can be combined by a factor $\mathrm{k}$ :

$$
\begin{array}{ll}
k=\sigma_{t} / \tau_{l t}=2 . d_{v} / h & \text { for } \mathrm{a} / \mathrm{h} \leq 0.5 \\
k=d_{v} / a[4 / 3-(2 / 3)(a / h)] & \text { for } 0.5<\mathrm{a} / \mathrm{h} \leq 2.0
\end{array}
$$

The stress $\sigma_{\mathrm{r}}$ can be found from equations (15 and 17) and the stress-strain relationship of steel:

$$
\begin{gathered}
\text { If } \epsilon_{\mathrm{t}}<\left(\epsilon_{\mathrm{y}}\right)_{\mathrm{t}} \quad \sigma_{r}=\frac{\sigma_{d}\left(k \cdot \sin \alpha \cdot \cos \alpha-\sin ^{2} \alpha\right)-\rho_{t} \cdot E_{s} \cdot \varepsilon_{t}}{k \cdot \sin \alpha \cdot \cos \alpha+\cos ^{2} \alpha} \\
\text { If } \epsilon_{\mathrm{t}} \geq\left(\epsilon_{\mathrm{y}}\right)_{\mathrm{t}} \quad \sigma_{r}=\frac{\sigma_{d}\left(k \cdot \sin \alpha \cdot \cos \alpha-\sin ^{2} \alpha\right)-\rho_{t} \cdot\left(f_{y}\right)_{t}}{k \cdot \sin \alpha \cdot \cos \alpha+\cos ^{2} \alpha}
\end{gathered}
$$


From the stress-strain relationship of steel and equations (15a and 16a) and assuming that $\left(\sigma_{l}=\right.$ $0)$, the value of $(\alpha)$ can be found:

$$
\begin{aligned}
& \text { If } \epsilon_{\mathrm{l}}<\left(\epsilon_{\mathrm{y}}\right)_{l} \quad \cos ^{2} \alpha=\frac{\sigma_{r}+\rho_{l} \cdot E_{s} \cdot \varepsilon_{r}}{\sigma_{r}-\sigma_{d}-\rho_{l} \cdot E_{s}\left(\varepsilon_{d}-\varepsilon_{r}\right)} \\
& \text { If } \epsilon_{\mathrm{l}} \geq\left(\epsilon_{\mathrm{y}}\right)_{l} \quad \cos ^{2} \alpha=\frac{\sigma_{r}+\rho_{l} \cdot\left(f_{y}\right)_{l}}{\sigma_{r}-\sigma_{d}}
\end{aligned}
$$

The above equations are solved iteratively to find the values of $\left(\varepsilon_{r}, \varepsilon_{d}, \sigma_{r}, \sigma_{d}, \alpha\right.$ and $\delta$ ), as shown in the following steps:

1- Calculate the value of $\mathrm{k}$ using Eq. (18),

2- Choose values for $\varepsilon_{d}$,

3- Assume a value for $\varepsilon_{r}$,

4- Calculate $\sigma_{r}$ from Eq. (12),

5- Calculate the value of $\delta$ from Eq. (5),

6- Calculate $\sigma_{d}$ from Eq. 1,

7- Calculate the value of $\alpha$ from Eq. (20),

8- Calculate $\sigma_{r}$ from Eq. (19),

9- Compare the values of $\sigma_{r}$ from steps (4 and 8), if the difference is $< \pm 5 \%$, the values of $\left(\varepsilon_{r}, \sigma_{r}, \sigma_{d}, \alpha\right.$ and $\delta$ ) are acceptable and the solution proceed to step 11,

10 - If the values of $\sigma_{r}$ differ by more than $\pm 5 \%$, the iterative process is repeated from step (3 -9) till the values converge,

11- Calculate the values of $\left(\tau_{l t}, \gamma_{l t}\right.$ and $\left.\mathrm{V}\right)$ from Eqs. (15c, 16c and 17a),

12-Steps (1-11) are repeated with other values of $\varepsilon_{d}$ till its maximum value is attained using Equation (4) which is the ultimate compressive strain.

\section{Results and Discussion Reinforced Concrete Deep Beams}

The above procedure and the materials constitutive relationships are used to analyze the ten fibre reinforced concrete deep beams whose test results are reported in reference [2]. Table (1) show the details of these beams. The longitudinal steel ratio $\left(\rho_{l}\right)$ for these beams represents the ratio of the tension and horizontal reinforcement. Another twelve fibre reinforced concrete deep beams whose test results are reported in reference by [1] are also analyzed in this investigation. Table (2) show the details of these beams. The longitudinal steel ratio $\left(\rho_{l}\right)$ for these beams represent the ratio of the tension reinforcement only, since no transverse reinforcement is provided.

Table (1) Properties of the Fibre Reinforced Concrete Deep Beams of reference [2]

\begin{tabular}{|c|c|c|c|c|c|}
\hline $\mathrm{b}(\mathrm{mm})$ & $\mathrm{h}(\mathrm{mm})$ & $\left(\mathrm{f}_{\mathrm{y}}\right)_{\mathrm{l}}(\mathrm{MPa})$ & $\left(\mathrm{f}_{\mathrm{y}}\right)_{\mathrm{t}}(\mathrm{MPa})$ & $\mathrm{l}_{\mathrm{f}} / \mathrm{d}_{\mathrm{f}}$ & Fibre type \\
\hline 90 & 500 & 440 & 375 & 53.2 & Hooked \\
\hline
\end{tabular}

Table (2) Properties of the Fibre Reinforced Concrete Deep Beams of reference [1]

\begin{tabular}{|c|c|c|c|c|c|}
\hline $\mathrm{B}(\mathrm{mm})$ & $\mathrm{H}(\mathrm{mm})$ & $\left(\mathrm{f}_{\mathrm{y}}\right)_{\mathrm{l}}(\mathrm{MPa})$ & $\rho_{\mathrm{l}}$ & $\mathrm{l}_{\mathrm{f}} / \mathrm{d}_{\mathrm{f}}$ & Fibre type \\
\hline 100 & 400 & 460 & 3.55 & 100 & Crimped \\
\hline
\end{tabular}

Tables (3 and 4) and Figs. (4 and 5) show that the shear strength decreases with the increase of shear span/depth ratio (as for slender beams) and increases with the fibres volume. Comparing 
the results of beams (B4, B10 with B9) in Table (3) show that the transverse reinforcement is more effective in increasing the shear strength than the longitudinal reinforcement for this $\mathrm{a} / \mathrm{h}$ ratio, while for larger $\mathrm{a} / \mathrm{h}$ ratios the longitudinal reinforcement is more effective.

Table (3) Shear Strength of the Fibre Reinforced Concrete Deep Beams [2]

\begin{tabular}{|c|c|c|c|c|c|c|c|c|}
\hline $\begin{array}{c}\text { Beam } \\
\text { No. }\end{array}$ & $\mathrm{a} / \mathrm{h}$ & $\begin{array}{c}f_{c}^{\prime} \\
\mathrm{MPa}\end{array}$ & $\begin{array}{c}\rho_{\mathrm{l}} \\
\%\end{array}$ & $\begin{array}{c}\rho_{\mathrm{t}} \\
\%\end{array}$ & $\begin{array}{c}\mathrm{V}_{\mathrm{f}} \\
\%\end{array}$ & $\begin{array}{c}V_{u, \text { test }} \\
\mathrm{kN}\end{array}$ & $\begin{array}{c}V_{u, \text { pred. }} \\
\mathrm{kN}\end{array}$ & $\begin{array}{c}V_{u, \text { pred. }} \\
V_{u, \text { test }}\end{array}$ \\
\hline B1 & 0.29 & 35.7 & 2.29 & 0.44 & 1.0 & 375 & 376 & 1.0 \\
\hline B2 & 0.57 & 35.7 & 2.29 & 0.44 & 1.0 & 360 & 374 & 1.04 \\
\hline B3 & 0.86 & 35.5 & 2.29 & 0.44 & 1.0 & 291 & 318 & 1.08 \\
\hline B4 & 1.14 & 31.1 & 2.29 & 0.44 & 1.0 & 228 & 223 & 0.98 \\
\hline B5 & 1.71 & 31.5 & 2.29 & 0.44 & 1.0 & 183 & 161 & 0.88 \\
\hline B6 & 1.14 & 34.4 & 2.29 & 0.44 & 0.0 & 205 & 233 & 1.14 \\
\hline B7 & 1.14 & 33.8 & 2.29 & 0.44 & 0.5 & 220 & 237 & 1.07 \\
\hline B8 & 1.14 & 33.2 & 2.29 & 0.44 & 1.5 & 260 & 266 & 1.02 \\
\hline B9 & 1.14 & 29.2 & 2.92 & 0.44 & 1.0 & 224 & 222 & 0.99 \\
\hline B10 & 1.14 & 30.1 & 2.29 & 1.21 & 1.0 & 290 & 287 & 0.99 \\
\hline
\end{tabular}

Table (4) Shear Strength of the Fibre Reinforced Concrete Deep Beams [1]

\begin{tabular}{|c|c|c|c|c|c|c|}
\hline $\begin{array}{c}\text { Beam } \\
\text { No. }\end{array}$ & $\mathrm{a} / \mathrm{h}$ & $f_{c}^{\prime} \mathrm{MPa}$ & $\mathrm{V}_{\mathrm{f}} \%$ & $\begin{array}{c}V_{u, \text { test }} \\
\mathrm{kN}\end{array}$ & $\begin{array}{c}V_{u, \text { pred. }} \\
\mathrm{kN}\end{array}$ & $\begin{array}{c}V_{u, \text { pred. }} \\
V_{u, \text { test }}\end{array}$ \\
\hline D1 & 0.6 & 43.1 & 0.0 & 316 & 307 & 0.97 \\
\hline D2 & 0.6 & 51.6 & 0.25 & 350 & 381 & 1.08 \\
\hline D3 & 0.6 & 49.8 & 0.50 & 325 & 368 & 1.14 \\
\hline D4 & 0.6 & 46.4 & 0.75 & 361 & 344 & 0.95 \\
\hline D5 & 0.6 & 54.6 & 1.00 & 396 & 411 & 1.04 \\
\hline D6 & 0.6 & 53.6 & 1.25 & 393 & 405 & 1.03 \\
\hline D7 & 0.4 & 49.3 & 1.00 & 454 & 401 & 0.88 \\
\hline D8 & 0.5 & 46.5 & 1.00 & 404 & 381 & 0.94 \\
\hline D9 & 0.7 & 44.5 & 1.00 & 342 & 301 & 0.88 \\
\hline D10 & 0.8 & 47.9 & 1.00 & 344 & 295 & 0.85 \\
\hline D11 & 0.6 & 30.2 & 1.00 & 294 & 205 & 0.7 \\
\hline D12 & 0.6 & 33.8 & 1.00 & 333 & 241 & 0.72 \\
\hline
\end{tabular}

The test results of beams D11 and D12 in Table (4) show that the compressive strength of concrete did not affect the shear strength, on the contrary of the predicted shear strength which exhibit this effect. Excluding the beams D11 and D12, the range of the predicted to the test values of the shear strength for the 20 beams varies from 0.85 to 1.14 with an average of 1.0 and a coefficient of variation of $8.2 \%$. However, the large deviation of some predicted results can be attributed to the small area or to the absence of the transverse reinforcement. 


\section{Al-Ta'a: Softened Truss Model Theory for the Analysis of Fibre Reinforced Concrete Deep}

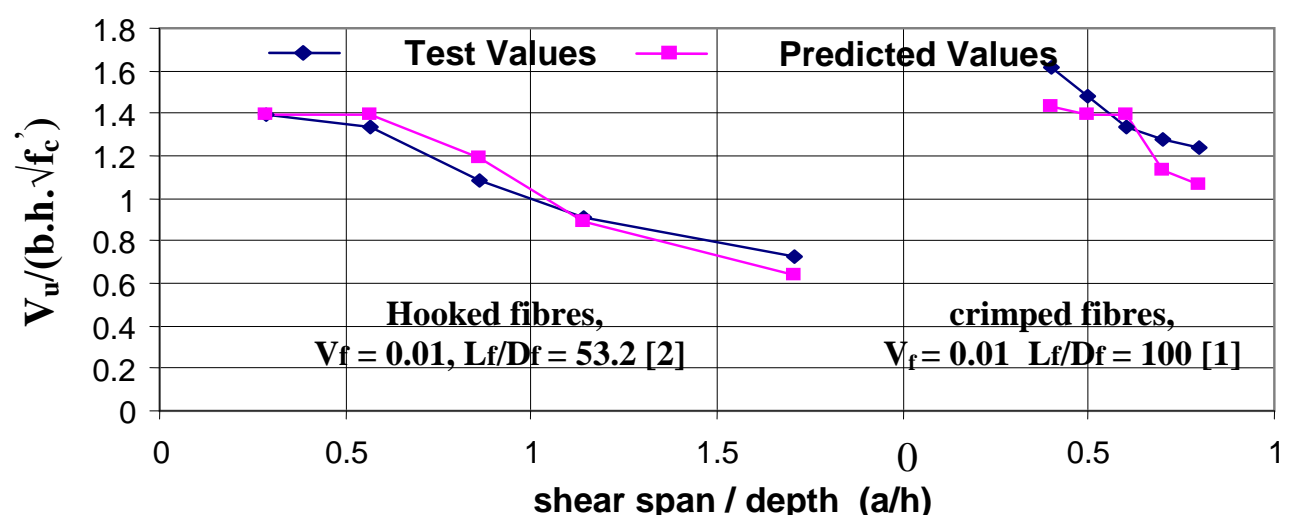

Figure (4) Variation of the normalized shear force with the shear span/depth ratio

\section{Reinforced Concrete corbels}

Since the corbel is a short cantilever deep beam, the above procedure and the materials constitutive relationships is used to analyze the twelve fibre reinforced concrete corbels whose test results are reported in reference [3]. Table (5) shows the details of these corbels. The longitudinal steel ratio $\left(\rho_{l}\right)$ for these corbels represents the ratio of the tension and horizontal reinforcement for corbels without steel fibres, while those containing steel fibres $\left(\rho_{l}\right)$ represent the ratio of the tension reinforcement. Table (6) and Fig. (6) show that the shear strength increases with the longitudinal steel ratio which represent the flexural and shear friction reinforcement. Table (6) and Fig. (7) show that the shear strength increases with the increase of fibres volume and the enhancement is more than that for the deep beams shown in Fig.(5) due to the smaller a/h ratio.

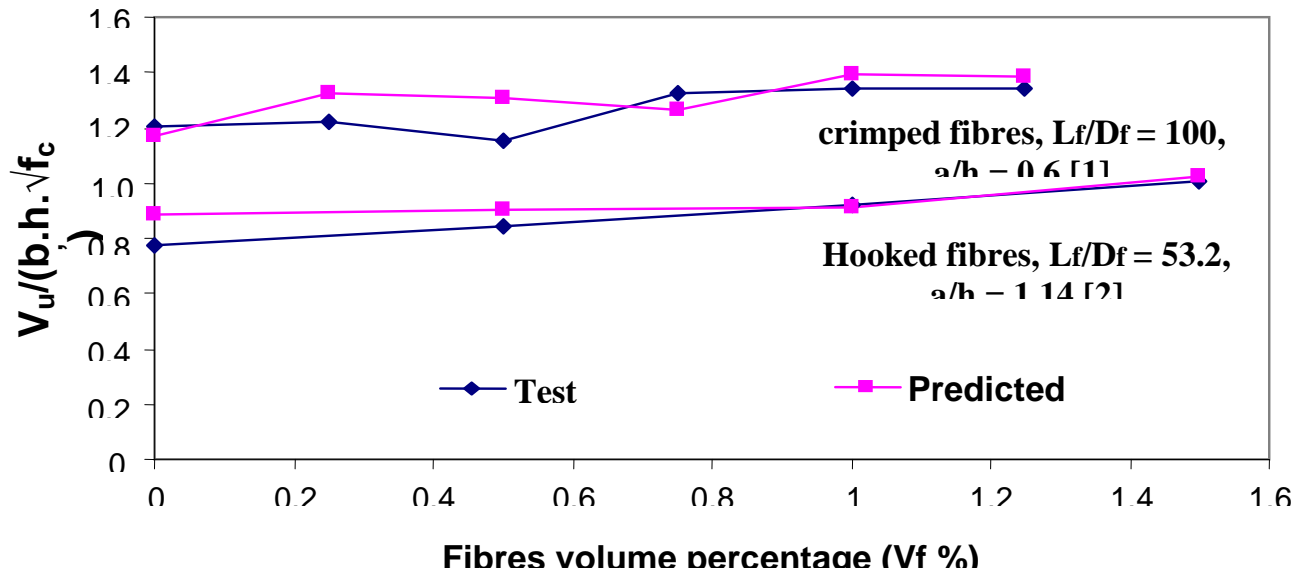

Figure (5) Variation of the normalized shear force with the fibres volume

Table (5) Properties of the Fibre Reinforced Concrete Corbels of reference [3]

\begin{tabular}{|c|c|c|c|c|c|c|}
\hline $\mathrm{b}(\mathrm{mm})$ & $\mathrm{h}(\mathrm{mm})$ & $\mathrm{a} / \mathrm{h}$ & $\left(\mathrm{f}_{\mathrm{y}}\right)_{\mathrm{l}}(\mathrm{MPa})$ & $\rho_{\mathrm{t}}$ & $\mathrm{l}_{\mathrm{f}} / \mathrm{d}_{\mathrm{f}}$ & Fibre type \\
\hline 150 & 150 & 0.59 & 460 & 0.0 & 85.5 & $\begin{array}{c}\text { Double } \\
\text { indented }\end{array}$ \\
\hline
\end{tabular}


Table (6) Shear Strength of the Fibre Reinforced Concrete Corbels [3]

\begin{tabular}{|c|c|c|c|c|c|c|c|}
\hline $\begin{array}{l}\text { Beam } \\
\text { No. }\end{array}$ & $f_{c}^{\prime} \quad \mathrm{MPa}$ & $\left(f_{y}\right)_{l}$ & $\rho_{l}$ & $\mathrm{~V}_{\mathrm{f}} \quad \%$ & $\begin{array}{c}V_{u, t e s t} \\
\mathrm{kN}\end{array}$ & $\begin{array}{c}V_{u, \text { pred }} \\
\mathrm{kN}\end{array}$ & $\frac{V_{u, \text { pred }}}{V_{u, \text { test }}}$ \\
\hline T1 & 43.1 & 558 & 0.7 & 0.0 & 93.2 & 99.5 & 1.06 \\
\hline T2 & 51.6 & 558 & 1.4 & 0.0 & 145.8 & 158.0 & 1.08 \\
\hline T3 & 49.8 & 558 & 0.7 & 0.7 & 133.0 & 129.6 & 0.97 \\
\hline $\mathrm{T} 4$ & 46.4 & 558 & 0.7 & 1.4 & 142.5 & 160.7 & 1.12 \\
\hline T5 & 54.6 & 558 & 0.7 & 2.1 & 143.0 & 171.0 & 1.19 \\
\hline T6 & 53.6 & 558 & 1.0 & 0.0 & 136.3 & 116.0 & 0.85 \\
\hline $\mathrm{T} 7$ & 49.3 & 491 & 1.7 & 0.0 & 156.6 & 151.0 & 0.96 \\
\hline T8 & 46.5 & 491 & 2.4 & 0.0 & 188.4 & 170.5 & 0.91 \\
\hline T9 & 44.5 & 491 & 2.4 & 0.0 & 153.4 & 161.0 & 1.05 \\
\hline $\mathrm{T} 10$ & 47.9 & 491 & 1.0 & 0.7 & 138.0 & 127.0 & 0.92 \\
\hline T11 & 30.2 & 491 & 1.0 & 1.4 & 160.2 & 159.0 & 0.99 \\
\hline T12 & 33.8 & 491 & 1.0 & 2.1 & 171.2 & 169.0 & 0.99 \\
\hline
\end{tabular}

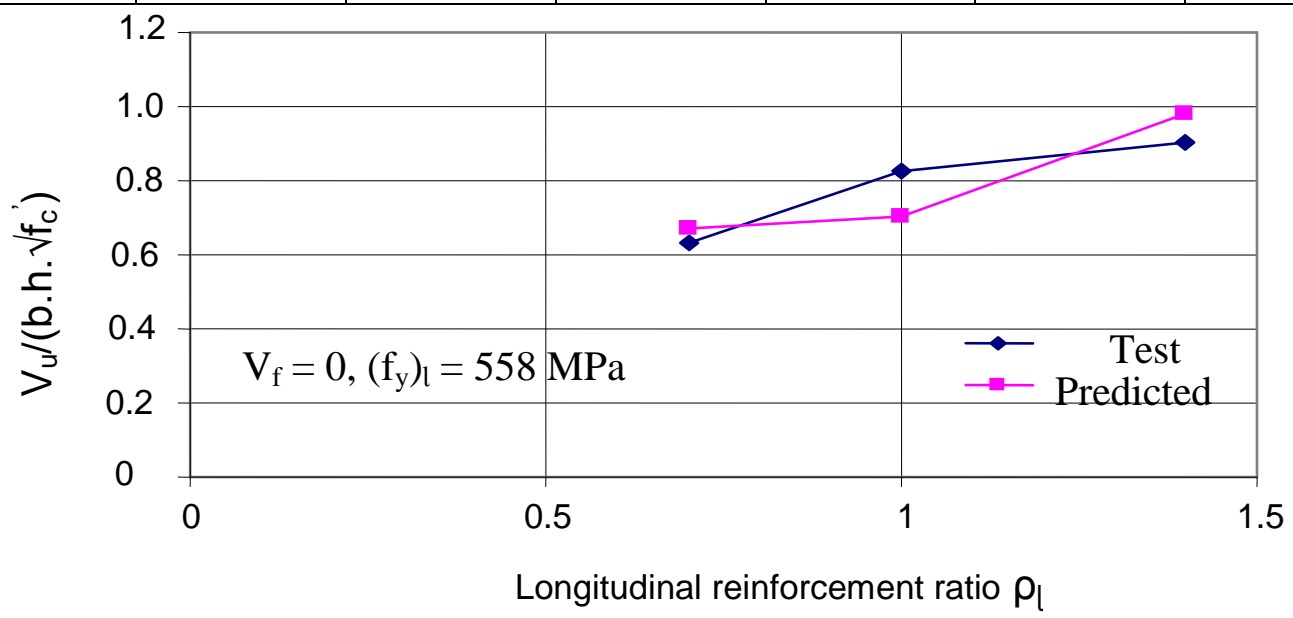

Figure (6) Variation of the normalized shear force with the longitudinal reinforcement ratio for the corbels

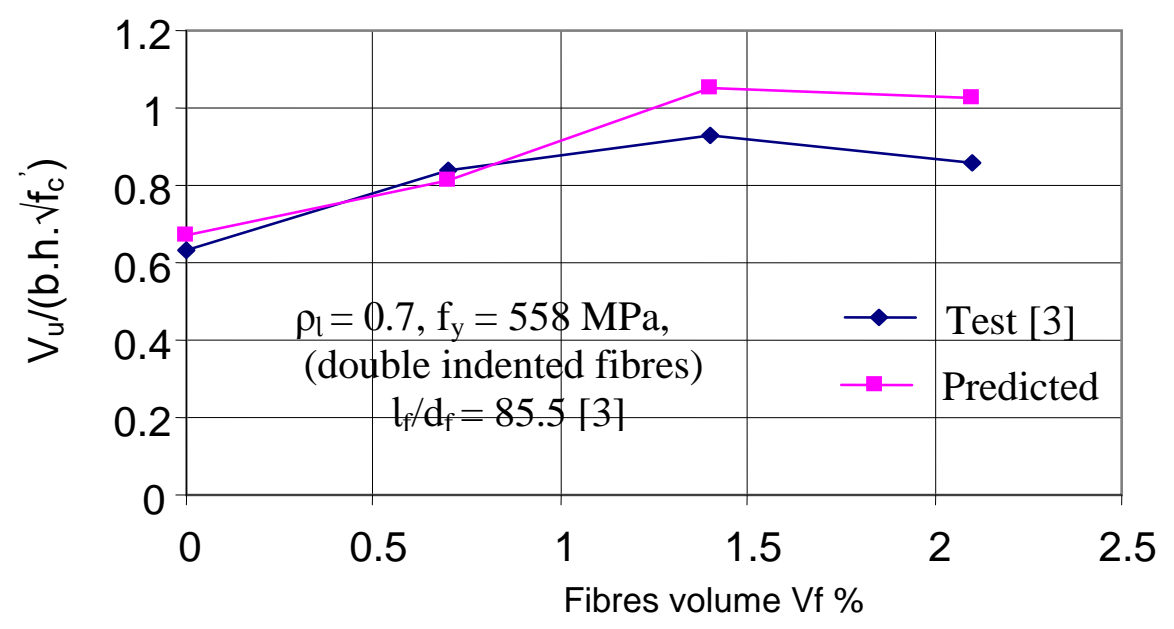

Figure (7) Variation of the normalized shear force with the fibres volume for the corbels 


\section{Al-Ta'a: Softened Truss Model Theory for the Analysis of Fibre Reinforced Concrete Deep}

\section{Conclusions}

The adopted softened truss model theory together with the materials constitutive relationships predicted the shear strength of fibre reinforced concrete deep beams and corbels with a reasonable accuracy. The influence of the shear span/depth ratio, longitudinal, transverse and steel fibre reinforcement were predicted on the shear strength of the analyzed specimens.

The method may be further developed to analyze fibre reinforced concrete members subjected to combined shear and torsion and to fibre prestressed concrete members.

\section{References}

1.Narayanan, R. and Darwish, I. Y.S., " Fibre Concrete Deep Beams in Shear", ACI Structural Jour., Vol. 85, No. 2, Mar. - April 1988, pp. 141-148.

2. Mansur, M. A. and Ong, K. C. G., " Behaviour of Reinforced Fibre Concrete Deep Beams in Shear", ACI Structural Jour., Vol. 88, No. 1, Jan. - Feb. 1991, pp. 98-105.

3. Fattuhi, N. I. and Hughes, B. P., " Ductility of Reinforced Concrete Corbels containing either Steel Fibres or Stirrups", ACI Structural Jour., Vol. 86, No. 6, Nov. - Dec. 1989, pp. 644651.

4. Hsu, T. T. C., Mau, S.T. and Chen, B., " Theory of Shear Transfer Strength of Reinforced Concrete", ACI Structural Jour., Vol. 84, No. 2, March - April, 1987, pp. 149-160.

5. Mau, S. T. and Hsu, T. T. C., " Shear Strength Prediction for Deep Beams with Web Reinforcement", ACI Structural Jour., Vol. 84, No. 6, Nov. - Dec. 1987, pp. 513-523.

6. Hsu, T. T. C., " Softened Truss Model Theory for shear and torsion", ACI Structural Jour., Vol. 85, No. 6, Nov. - Dec. 1988, pp. 624-635.

7. Mo, Y. L. and Kou, J. Y., " Experimental Studies on Low Rise Structural Walls", Materials and Structures, Vol. 31, No. 211, Aug. - Sept., 1998, pp. 465-472.

8. Mo, Y. L. and Rothert, H., " Effect of Loading Rate on Softening Behaviour of Low Rise Structural Walls", Structural Engineering and Mechanics, Vol. 5, No. 6, Nov., 1997, pp. 729741.

9. Hsu, T. T. C., " Nonlinear Analysis of Concrete Torsional Members", ACI Structural Jour., Vol. 88, No. 6, Nov. - Dec. 1991, pp. 674-682.

10. B.R Niranjan, B. R. and Patil, S. S., " Shear Strength Prediction of Deep Beams by Softened Truss Model", IOSR Journal of Mechanical and Civil Engineering (IOSR-JMCE), Vol. 4, Issue 1, Nov. - Dec. 2012, pp. 1- 6.

11. ACI committee (544.1 R-96), "State - of - The Art Report on Fiber Reinforced Concrete", American Concrete Institute, 1996, pp.1-66.

12. Hsu, C.T.T., He, R.L., and Ezeldin, A.S., " Load-Deformation Behavior of Steel Fiber Reinforced Concrete Beams". ACI Structural Jour., Vol. 89, 1992, 650-657.

13. Soroushian, P. Lee, C.D., "Constitutive Modeling of Steel Fiber Reinforced Concrete under Direct Tension and Compression", Proc. of the International Conference on Recent Developments in Fiber Reinforced Cements and Concretes, Sept. 1989, Cardiff, UK., Elsevier applied science publisher, pp. 363-377.

14. Abdul-Razzak, "Nonlinear Finite Element Analysis of Fibrous Reinforced Concrete Structural Members", Ph.D. Thesis, Mosul University, Iraq, 1996, pp. 74-83. 
15. Belarbi, A. and Hsu, T. T. C., " Constitutive Laws of Softened Concrete in Biaxial TensionCompression", ACI Struc. Jour., Vol. 92, 1995, No. 5, Sept. - Oct. 1995, pp. 141-148.

16. Al-Ta'an, S. A. and Ezzadeen, N. A., " Flexural Analysis of Reinforced Fibrous Concrete Members using the Finite Element Method", Jour. of Computers and Structures, Vol. 56, No. 6, Sept. 1995, pp. 1065-1072.

17. Sakai, M. and Nakamura, N., " Analysis of Flexural Behaviour of Steel Fiber Reinforced Concrete", Proc. of the Rilem on Developments in Fiber Reinforced Cements and Concretes, Technical Committee 49-TFR, 13-17 July 1986, Sheffield, UK., pp. 27-34.

18. Al-Husaini, N. S. H. M., "Softened Truss Model Theory for Analysis of Reinforced Fibrous Concrete Members under Shear and Torsion", M. Sc. Thesis, Mosul University, Iraq, 2001, 95pp.

19. Carraquillo, R.L., Nilson, A.H. and Slate, F.O., " Properties of High Strength Concrete Subjected to Short Term Loads", ACI Journal, Proceedings, Vol. 78, No. 8, May-June 1981, pp.171-178. 